\title{
Assessing the Improvement Effect of the New Advanced Cancer Nursing Role on Gastrointestinal Cancer Patients
}

\author{
Danmei Weng, Zhaolin Chen*, Yanyun Chen, Xiaoxi Cai \\ Gastroenterology Department, The First Affiliated Hospital of Jinan University, Guangzhou, China \\ Email address: \\ 1024338913@qq.com (Danmei Weng),2009gzjnu@163.com (Zhaolin Chen),499324016@qq.com (Yanyun Chen), \\ 2206997396@qq.com (Xiaoxi Cai) \\ ${ }^{*}$ Corresponding author
}

\section{To cite this article:}

Danmei Weng, Zhaolin Chen, Yanyun Chen, Xiaoxi Cai. Assessing the Improvement Effect of the New Advanced Cancer Nursing Role on Gastrointestinal Cancer Patients. International Journal of Gastroenterology. Vol. 4, No. 1, 2020, pp. 20-23. doi: 10.11648/j.ijg.20200401.15

Received: February 26, 2020; Accepted: March 6, 2020; Published: March 17, 2020

\begin{abstract}
Objective: To evaluate the improvement effect of the new advanced cancer nursing role on gastrointestinal cancer patients. Methods: 208 patients who were diagnosed as gastrointestinal cancer in The First Affiliated Hospital of Jinan University from May 2016 to October 2019 were randomly assigned to intervention group and control group. The patients of two group received different nursing measure. In control group, the patients received traditional nursing services in the treatment process. Besides, the patients of intervention group received additional nursing services, such as the new advanced cancer nursing role. We collected the information of participants by questionnaires and patient record, such as patients' experience of coordination, quality of life (QoL) and supportive care resources. Moreover, we collected data using the following questionnaires; the Treatment of Cancer Quality of Life Questionnaire, QLQ-C30 and QLQ-INFO25 and also a study specific questionnaire. Result: In result of different groups, the participants of intervention group had better performance than that of control group $(59.31 \pm 25.41$ vs $55.66 \pm 24.12,66.71 \pm 26.84$ vs $67.61 \pm 26.38,58.44 \pm 25.51$ vs $50.97 \pm 25.13,35.67 \pm 28.81$ vs $29.87 \pm 27.14)$. In assessment of supportive care resources, only the result of second question had a lot of gap, which is 'Did you get information about how to contact the health care provider outside office time?' [57 (54.8\%) vs 64 (61.5\%)]. Conclusion: The improvement effect of the new advanced cancer nursing role is obvious for the patients. Besides, the perceived information status of intervention group was improved in the result.
\end{abstract}

Keywords: Advanced Cancer Nursing Role, Gastrointestinal Cancer, Nursing

\section{Introduction}

The advanced nursing roles is a new conception in the hospital, such as Clinical Nurse Specialists, (CNS), Nurse Practitioner (NP) and Advanced Nurse Practitioner (ANP), they are clinical expert roles with academic degrees, master or higher $[1,2]$. Base on reports, health care delivered by nurses in these advanced roles can improve important care quality, which have proven to impact factors in the treatment process $[3,4]$. The improvement included safety, symptom-burden, experiences of patients and cancer care coordination [5]. In 2015 and 2017, Dr. McDonnell and Bell report that the advanced nursing roles will provide more advantages in work process, it not only can reduce readmissions but also contribute to the improvement of other staff members' skills and competences $[6,7]$. For example, the Sweden's National
Cancer plan, a part of its plan is that every cancer patient should be offered a contact nurse, as their main point of contact through the cancer journey [8]. The contact nurse is a clinical nursing role with in-depth knowledge in cancer care, supporting patients and their families during the cancer trajectory [9].

Gastrointestinal cancer is the leading cause of death in China and is the major public health problem [10]. Base on the reports, the emphasis of cancer research is not only intrinsic (proto-oncogene and antioncogene), but also extrinsic (tumor microenvironment) [11]. And the tumor microenvironment was influenced by treatment environment and patient status. So the advanced nursing roles had influence to treatment outcome of gastrointestinal cancer patients in the treatment process $[12,13]$. The aim of this research is assessing the improvement effect of the new advanced cancer nursing role 
on gastrointestinal cancer patients in Chinese hospital.

\section{Methods}

\subsection{Participants Enrollment}

All patients, their age were 18 years old or higher, diagnosed in May 2016 and October 2019 respectively with gastrointestinal cancer in The First Affiliated Hospital of Jinan University were invited to participate. After invited step, the participants $(n=208)$ were randomly assigned to two groups, that included a control group $(\mathrm{n}=104)$ and a intervention group $(n=104)$. The two groups were received different nursing measure in treatment process. For control group, the participants were received traditional nursing measures which is the standard of nursing measure by the hospital. For intervention group, we provided the advanced nursing roles to the nursing measure of the participants, our different professionals is responsible for nursing care in their respective professions. In treatment process, we collected the information of participants, such as patients' experience of coordination, quality of life (QoL) and supportive care resources. We collected data using the following questionnaires; the Treatment of Cancer Quality of Life Questionnaire, QLQ-C30 and QLQ-INFO25 and also a study specific questionnaire $[14,15]$. Other information was from our researchers and patients' record in the treatment process. All participants have signed informed consent forms before they join our study, they were voluntary acceptance of new nursing measure in treatment process.

Their inclusion criteria were: (1) the patients were diagnosed as gastrointestinal cancer; (2) Patients volunteered to participate in post-treatment follow-up; (3) their mental status were healthy. Their withdraw criteria were: (1) Survival is expected to be less than 90 days; (2) Patients with severe vital organ dysfunction or related mental illness.

\subsection{Statistical Analysis}

Survey responses were analyzed using descriptive statistics. Sample proportions, means, and standard deviation (SD) are reported. All analyses were performed in SPSS 24.

\section{Result}

For the total sample, the score of all projects was low level or middle level in our research, especially information about other services, it is only half the other scores in the result (Table 1). In result of different groups, the participants of intervention group had better performance than that of control group $(59.31 \pm 25.41$ vs $55.66 \pm 24.12,66.71 \pm 26.84$ vs $67.61 \pm 26.38,58.44 \pm 25.51$ vs $50.97 \pm 25.13,35.67 \pm 28.81$ vs $29.87 \pm 27.14)$. The data of information about other services had a lot of gap between two groups, the participant performance had more significant improvements. We also found the following statistically significant improvements at result regarding the QLQ-C30 and QLQ-INFO25 items ( $\mathrm{p}<$ 0.001).

Table 1. Patient reported perceived Information needs the Treatment of Cancer Quality of Life Questionnaire, QLQ-C30 and QLQ-INFO25.

\begin{tabular}{|c|c|c|c|c|}
\hline Projects & $\begin{array}{l}\text { Information about the } \\
\text { disease }\end{array}$ & $\begin{array}{l}\text { Information about the } \\
\text { medical tests }\end{array}$ & $\begin{array}{l}\text { Information about } \\
\text { treatments }\end{array}$ & $\begin{array}{l}\text { Information about other } \\
\text { services }\end{array}$ \\
\hline Control Group $(\mathrm{n}=104)$ & $55.66 \pm 24.12$ & $66.71 \pm 26.84$ & $50.97 \pm 25.13$ & $29.87 \pm 27.14$ \\
\hline Intervention Group $(\mathrm{n}=104)$ & $59.31 \pm 25.41$ & $67.61 \pm 26.38$ & $58.44 \pm 25.51$ & $35.67 \pm 28.81$ \\
\hline P-value & 0.029 & 0.051 & 0.012 & $<0.001$ \\
\hline 95\% CI lower/upper & {$[-3.15 / 1.67]$} & {$[-3.57 / 1.76]$} & {$[-5.10 / 0.01]$} & {$[-8.33 / 2.76]$} \\
\hline
\end{tabular}

The data of supportive care resources from patients report, they complete the questionnaires in treatment process (Table 2 ). The data of supportive care resources included 4 main questions in research, they had different assessment answers. In two groups, only the result of second question had a lot of gap, which is 'Did you get information about how to contact the health care provider outside office time?' [57 (54.8\%) vs $64(61.5 \%)]$. But other results has the gap is not big in the research result.

Table 2. Patients reported access to supportive care resources, $n(\%)$.

\begin{tabular}{|c|c|c|c|c|}
\hline Projects & $\begin{array}{l}\text { How do you experience the } \\
\text { access to contact nurse } \\
\text { when you needed one? }\end{array}$ & $\begin{array}{l}\text { Did you get information about } \\
\text { how to contact the health care } \\
\text { provider outside office time? }\end{array}$ & $\begin{array}{l}\text { Did you get the support } \\
\text { you wanted in your } \\
\text { parental role? }^{\text {b }}\end{array}$ & $\begin{array}{l}\text { Do you know why you } \\
\text { had a referral to } \\
\text { palliative care? }^{\text {b }}\end{array}$ \\
\hline Control Group $(n=104)$ & $92(88.5 \%)$ & $57(54.8 \%)$ & $22(21.2 \%)$ & $77(74.0 \%)$ \\
\hline Intervention Group $(n=104)$ & $91(87.5 \%)$ & $64(61.5 \%)$ & $27(26.0 \%)$ & $82(87.8 \%)$ \\
\hline P-value & 0.462 & 0.030 & 0.814 & $<0.001$ \\
\hline
\end{tabular}

${ }^{\mathrm{a}}$ Very good and Good.

${ }^{b}$ Yes.

Among the five items related to patients' experience of coordination in care transitions, we found statistically significant differences regarding three of the items in the result (Table 3). Most of result had small gap between intervention group and control group. Except for the third question which is 'Did the health care providers transfer information from palliative care and acute cancer care without the need for you to be responsible?', the participants of intervention group had better services in research $[79(75.96 \%)$ vs $53(51.0 \%)]$. 
Table 3. Patient perception of involvement in and coordination of care, $n(\%)$.

\begin{tabular}{llllll}
\hline & $\begin{array}{l}\text { Did you have the } \\
\text { possibility to ask } \\
\text { questions regarding } \\
\text { your care and } \\
\text { treatment if there } \\
\text { was something you } \\
\text { didn't understand? }\end{array}$ & $\begin{array}{l}\text { Did you wish to } \\
\text { have more } \\
\text { influence } \\
\text { regarding } \\
\text { Pecision-making } \\
\text { related to your } \\
\text { treatment? }\end{array}$ & $\begin{array}{l}\text { Did the health care } \\
\text { providers transfer } \\
\text { information from } \\
\text { palliative care and } \\
\text { acute cancer care } \\
\text { without the need for }\end{array}$ & $\begin{array}{l}\text { Did you understand } \\
\text { why care transitions } \\
\text { where needed? Did } \\
\text { the staff explain to } \\
\text { you why the care } \\
\text { transitions were }\end{array}$ & $\begin{array}{l}\text { Did you experience } \\
\text { that you were } \\
\text { informed and } \\
\text { involved in planning } \\
\text { of your care } \\
\text { transitions? }\end{array}$ \\
& $88(84.6 \%)$ & $15(14.4 \%)$ & $53(51.0 \%)$ & $65(62.5 \%)$ & $54(51.9 \%)$ \\
& $86(82.7 \%)$ & $16(15.4 \%)$ & $79(75.96 \%)$ & $67(64.4 \%)$ & $61(58.7 \%)$ \\
\hline Control Group $(\mathrm{n}=104)$ & 0.663 & 0.042 & $<0.001$ & 0.175 & 0.009 \\
Intervention Group $(\mathrm{n}=104)$ & & & & \\
P-value & & & & \\
\hline
\end{tabular}

\section{Discussion}

Transforming roles in community nursing forms part of a broader United Kingdom (UK) government strategy to modernise and redesign the health service workforce [16]. Because given increasing economic constraints arising from the global recession, attempts to improve the effectiveness and efficiency of western healthcare workforces will doubtless continue for the foreseeable future [17]. Base on the boundaries between nursing and medicine with the rapid development of advanced practitioner and community matron roles, the resultant proliferation of transformed nursing roles is evident in some rich countries, such as UK and USA. For example, in UK, community matron is a term to describe experienced nurses with advanced clinical skills, responsible for the complex care coordination of people with long term conditions [18]. However, medicine and nursing opposition to advanced nursing roles and doubts over role legitimacy and relevance is evident in other western healthcare systems including Australia and Canada [19].

Base on the result of our study, the improvement effect of the new advanced cancer nursing role is obvious for the patients. Base on patient reported perceived information needs, the perceived information status of intervention group was improved in the result, especially information about treatment and information about other services, the status of those two domains had significant changing from patient report. In addition, the assessment of supportive care resources, although the total changing was better, the improvement effect was not obvious in the outcome. In assessment of involvement in and coordination of care, the status which the health care providers transfer information had great improvement in intervention group reports. The contact nurse provided satisfactory service in the treatment process, because the contact nursing play a important role in transfer information process.

\section{References}

[1] European Oncology Nursing Society, 2018. EONS Cancer Nursing Education Framework. 2018.

[2] Gerrish K, McDonnell A, Kennedy F. The development of a framework for evaluating the impact of nurse consultant roles in the UK. J. Adv. Nurs. 2016; 69 (10): 2295-2308.
[3] Newhouse RP, Stanik-Hutt J, White KM, Johantgen M, Bass EB, Zangaro G, Weiner JP. Advanced practice nurse outcomes 1990-2008: a systematic review. Nurs. Econ. 2016; 29 (5): 230-250.

[4] Aiken LH, Sloane DM, Bruyneel L, Van den Heede K, Griffiths P, Busse R, et al. Nurse staffing and education and hospital mortality in nine European countries: a retrospective observational study. Lancet. 2014; 383 (9931): 1824-1830.

[5] Jeyathevan G, Lemonde M, Cooper Brathwaite A. The role of oncology nurse navigators in facilitating continuity of care within the diagnostic phase for adult patients with lung cancer. Can. Oncol. Nurs. 2017; 27 (1): 7.

[6] McDonnell A, Goodwin E, Kennedy F, Hawley K, Gerrish K, Smith C. An evaluation of the implementation of Advanced Nurse Practitioner (ANP) roles in an acute hospital setting. J. Adv. Nurs. 2015; 71 (4): 789-799.

[7] Bell JF, Whitney RL, Reed SC, Poghosyan H, Lash RS, Kim KK, et al. Systematic review of hospital readmissions among patients with cancer in the United States. Oncol. Nurs. Forum. 2017; 44 (2), 176-191.

[8] Swedish Government Official Reports SOU, (in Swedish). En nationell cancerstrategi för framtiden. 2009: 11.

[9] Bjuresäter K, Larsson M. Patients' views of quality of care related to different models of contact nurse in Swedish cancer care. BMC Nurs. 2017: 16.

[10] Backes C, Sedaghat-Hamedani F, Frese K, Hart M, Ludwig N, Meder B, Meese E, Keller A, Bias in high-throughput analysis of miRNAs and implications for biomarker studies, Anal. Chem. 2016; 88: 2088-2095.

[11] Cai Q, Wang ZQ, Wang SH, Li C, Zhu ZG, Quan ZW, Zhang WJ, Upregulation of long non-coding RNA LINC00152 by SP1 contributes to gallbladder cancer cell growth and tumor metastasis via PI3K/AKT pathway, Am. J. Transl. Res. 2016; 8: 4068-4081.

[12] Bray F, Ferlay J, Soerjomataram I, Siegel RL, Torre LA, Jemal A. Global cancer statistics 2018: GLOBOCAN estimates of incidence and mortality worldwide for 36 cancers in 185 Countries. Cancer J Clin 2018; 68: 394-424.

[13] Tao R, Krishnan S, Bhosale PR, Javle MM, Aloia TA, Shroff RT, et al. Ablative radiotherapy doses lead to substantial prolongation of survival in patients with inoperable intrahepatic cholangiocarcinoma: a retrospective dose response analysis. J Clin Oncol 2016; 34 (3): 219-226.

[14] Fayers PM, Aaronson NK, Bjordal K, Groenvold M, Curran D, Bottomley A. The EORTC QLQ-C30 Scoring. 2001. 
[15] Arraras JI, Greimel E, Sezer O, Chie WC, Bergenmar M, Costantini A, et al. An international validation study of the EORTC QLQ-INFO25 questionnaire: an instrument to assess the information given to cancer patients. Eur. J. Cancer. 2010; 46 (15): $2726-2738$.

[16] Flynn R, Scott SD, Rotter T \& Hartfield D. The potential for nurses to contribute to and lead improvement science in health care. Journal of Advanced Nursing. 2017; 73 (1): 97-107.

[17] Puchalski Ritchie LM, KhanS, MooreJE, TimmingsC van Lettow M, Vogel J P, Straus SE. Low- and middle-income countries face many common barriers to implementation of maternal health evidence products. Journal of Clinical Epidemiology. 2016; 76: 229-237.

[18] Department of Health. The NHS Improvement Plan: Putting People at the Heart of Public Services. Department of Health, London. 2014.

[19] Elsom S, Happell B, Manias E. Nurse practitioners and medical practice: opposing forces or complementary contributions? Perspectives in Psychiatric Care. 2009; 45: 9-16. 